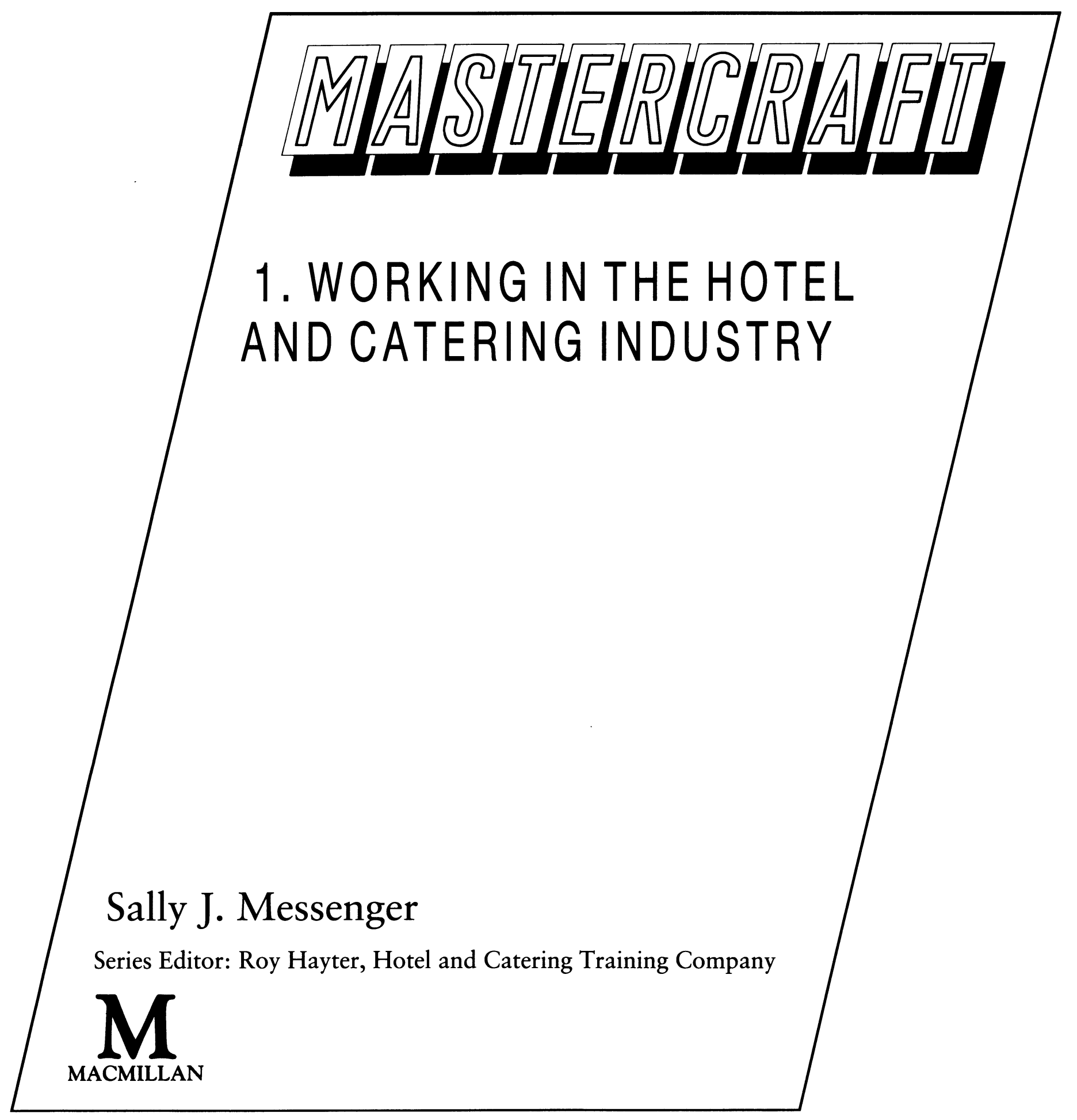


(C) Hotel and Catering Training Company 1990

All rights reserved. No reproduction, copy or transmission of this publication may be made without written permission.

No paragraph of this publication may be reproduced, copied or transmitted save with written permission or in accordance with the provisions of the Copyright, Designs and Patents Act 1988 or under the terms of any licence permitting limited copying issued by the Copyright Licensing Agency, 33-4 Alfred Place, London WC1E 7DP.

Any person who does any unauthorised act in relation to this publication may be liable to criminal prosecution and civil claims for damages.

First published 1990

Published by

MACMILLAN EDUCATION LTD

Houndmills, Basingstoke, Hampshire RG21 2XS

and London

Companies and representatives

throughout the world

Printed in Great Britain by

Scotprint Ltd, Musselburgh

British Library Cataloguing in Publication Data

Messenger, Sally J.

Working in the hotel and catering industry. - (HCTB/

Macmillan mastercraft 1)

1. Great Britain. Hotel and catering industry

I. Title II. Series

338.476479441

ISBN 978-0-333-45788-7

DOI 10.1007/978-1-349-09984-9 
Acknowledgements

\section{The industry}

1 Hotels, catering, leisure and tourism 2

2 More about the industry 4

3 Working in hotels and catering 6

4 What goes on in the kitchen 8

5 What goes on in food service 10

6 What goes on in the bar $\quad 12$

7 What goes on in housekeeping 14

8 What goes on in reception 16

9 Working in tourism and leisure 1

10 Working in tourism and leisure 2 20

11 Behind the scenes 22

\section{Working in the industry}

12 Getting qualified 24

13 Learning and study skills 26

14 A new job? $\quad 28$

15 Rules and regulations $\quad 30$

\section{Working with people}

16 Communication in the industry 32

17 Speaking and listening $\quad 34$

18 Non-verbal communication $\quad 36$

19 Written information $1 \quad 38$

20 Written information $2 \quad 40$

21 Written information $3 \quad 42$

22 Using the telephone 44

23 Finding information 46

24 Personal skills $\quad 48$ 


\section{Working efficiently}

25 The way you work 1

26 The way you work 2

27 The way you work $3 \quad 54$

28 Using equipment and materials 56

29 Working with others 58

30 Avoiding waste $1 \quad 60$

31 Avoiding waste 2 62

32 Controlling stock 64

\section{Working with numbers}

33 In the industry 66

34 Adding and subtracting $1 \quad 68$

35 Adding and subtracting $2 \quad 70$

36 Multiplying $\quad 72$

37 Dividing 74

38 Averages and ratios 76

39 Percentages $1 \quad 78$

40 Percentages $2 \quad 80$

41 Interpreting information $\quad 82$

42 Presenting information $\quad 84$

43 Estimating $\quad 86$

44 Measuring $1 \quad 88$

45 Measuring $2 \quad 90$

46 Financial control 1

47 Financial control 2

48 Financial control $3 \quad 96$

49 Financial control $4 \quad 98$

Working with I.T.

50 Understanding computers 100

51 How computers work 1 
52 How computers work 2 104

53 What computers can do 106

54 Computers in reception 108

55 Computers in food and beverage operations 110

56 Computers to control 112

57 Computers in accounting $\quad 114$

58 Computers behind the scenes 116

59 Integrated computer systems 118

$\begin{array}{ll}60 \text { Communication systems } & 120\end{array}$

$\begin{array}{ll}\text { Index } & 122\end{array}$ 
Macmillan Education and the Hotel and Catering Training Company are grateful to Mary James, Melvyn Teare and Tricia Wright for their help in setting up the scope and content of this book and for commenting on the draft text, and to Jessica Kuper and Jennifer Murray who helped edit the text. The publishers would also like to express sincere thanks to the following for their help in supplying photographs and illustrations:

Anglo-Welsh Waterway Holidays, Market Harborough (unit 45)

Ashridge Management Centre (unit 27)

Barbican Centre, London (unit 1)

Beefeater Steakhouses, Surbiton (units 15 and 55)

Catherine Blackie (picture research and photography in units 5, 15, 21, 22, 24, $25,26,28,30,31,32,34,38,41,46$ and 55)

Brasserie on the Hill, London SW11 (unit 16)

British Travel Brief, British Tourist Authority (units 40 and 42)

Brook Hotel, Felixstowe (units 14, 16, 18 and 48, photographer Edward Morgan)

Chris Browning (unit 33)

Burford Bridge Hotel (Trusthouse Forte), Box Hill, Dorking (cover, photographer Transmedia)

Butlins Holiday Worlds (unit 10)

Caterer \& Hotelkeeper and Army Catering Corps (unit 55), and Rediffusion (unit 60), and Bally Sall/Pinnacle Hygiene Systems (unit 42), and David Goymour/ Berkeley Scott (unit 40)

Copthorne Hotels (unit 8, Manchester, unit 16, Glasgow, unit 25)

The Crane, Wandsworth, London (unit 21)

Crest Hotels Ltd (units 1, 3, 8 and 11, Gloucester, unit 10, Bristol, unit 29)

Cromwell Hospital, Kensington, London (unit 22)

Alexia Cross (photography in units 4, 6, 7, 26, 28, 30, 31, 33, 41, 48, 49 and 55)

Cunard (unit 27)

Dorset Institute of Higher Education, Poole (unit 41, photographer David Spears)

Excelsior Hotel (Trusthouse Forte), Birmingham (unit 8)

Flemings Hotel, Mayfair, London (units 22, 24, 31 and 46)

Fretwell-Downing Data Systems, Sheffield (unit 56)

Granada Motorway Services Ltd, Heston Services M4 (units 26 and 41)

Great Eastern Hotel, London (units 1, 12 and 18)

Greenall Whitley (unit 17)

Grundy/Finessa Food Distribution Systems (unit 27)

Guidepost Hotel, Bradford (unit 7)

Harrogate International Conference and Exhibition Centre (unit 49)

Hedley House, York (unit 47)

Holiday Inn Heathrow (unit 54)

Horse and Groom, Alresford (unit 57)

Inn on the Park, Mayfair, London (unit 30)

InterCity On Board Services (unit 27)

Stephen James (unit 10)

Just Brahms Wine Bar and Bistro, Salisbury (unit 53)

Lanzarote Villas, Horsham (unit 45)

Little Chef (units 1 and 18)

London Tara Hotel, Kensington, London (units 7, 25, 26, 28, 30, 31, 33, 41, 48 and 49) 
Lucas CAV, Acton, London (Sutcliffe Catering (South) Ltd) (unit 31)

Robin Mathams (units 1, 3, 7, 10, 11, 16, 17, 27 and 33)

Maxwells Fish Restaurant, Ealing, London (unit 5)

Mecca Leisure Group plc (unit 25)

Network (units 9 and 43, photographer Chris Kelly)

Payne and Gunter Ltd (unit 26)

Picture Link (units 1, 6, 12, 13, 18, 23, 25 and 50)

Portman Arms (a Berni Inn), London NW1 (unit 26)

The Princess Louise, High Holborn, London (units 28, 31 and 32)

Remanco Systems Ltd, Twickenham (unit 55) and Smollenskys Balloon (unit

56)

The Ritz, London (unit 6)

Rumours Restaurants Ltd, London WC2 (unit 38)

Safety Signs Ltd (unit 41)

Saracens Head (Whitbread Ltd) (unit 27)

Sheraton Edinburgh (unit 16)

Sheraton Skyline Hotel, Hayes (units 4, 5, 6 and 55)

Sloop Inn, Devon (unit 34)

The Swiss Centre, London (unit 25)

Time Off Limited, London (units 41 and 44)

Tjaereborg (unit 43)

The Tower Thistle Hotel, London (unit 53)

Travellers Fare Ltd (units 5 and 33)

Trusthouse Forte Hotels (units 18 and 54)

Turnberry Hotel, Ayr (units 27 and 33)

XI Data Systems, Leeds (units 50, 56 and 59), and Midland Hotel (unit 51), and Chevin Hotel (unit 60)

Zazou, London W1 (unit 53) 
The hotel and catering industry is a diverse one, with job opportunities in a wide range of establishments from small guesthouses to leisure centres, restaurants, bars, theatres and cinemas. Customer needs vary from the basic requirement for accommodation, food and drink, to the sophisticated pleasures such as those offered on a luxury cruise.

Working in the industry is about understanding customer needs and providing for these needs in a way which meets the objectives of the operation. This means understanding something about the structure of the industry, about the qualification routes available to those who want to get on and becoming familiar with various rules and regulations.

Working in the industry also means working with other members of staff, with supervisors and managers, communicating effectively and doing the job efficiently. Many jobs involve working with numbers-from the simpler calculations required to adjust a recipe to the more complex workings involved in the analysis of operational results, preparation of budgets and financial control. Nowadays many of these tasks are done by computer, and information technology is playing an increasingly important role in meeting customer expectations, whether it be for accurate, fast billing, or a wider choice of television programmes.

\section{The structure of the book}

The book is divided into 60 self-contained units, grouped into six major subject areas.

The industry -an overview of the industry and more about the principal areas of work: the kitchen, food service, the bar, housekeeping, reception, tourism and leisure.

Working in the industry - getting qualifications, learning and study skills, starting a job, the rules and regulations relating to employment, health, hygiene and safety. Working with people-the communication skills: speaking, listening, body language, written information, using the telephone, finding and filing information and personal skills.

Working efficiently - the way you work, using equipment and materials, teamwork, avoiding waste and controlling stocks.

Working with numbers-adding and subtracting, multiplying and dividing, averages and ratios, percentages, interpreting and presenting information, estimating, measuring and financial control.

Working with technology - how computers work and the use of information technology in reception, food and beverage operations, control, accounting, in other behind the scenes activities and in communication systems.

Units that will help readers gain Caterbase introductory modules are identified and each unit has a TO DO. These practical activities will encourage readers to develop an interest in a particular topic and gain a deeper understanding by applying the information to their own experience. 